\title{
A Collaborative Research Initiative for the Environmental Management of Ostrich Production'
}

\section{Author(s)}

Rodrigues $\mathrm{GS}^{1 *}$

Buschinelli CC de $A^{1}$

Rodrigues $\mathrm{I}^{2}$

Medeiros $C B^{3}$

Researcher, Embrapa Meio Ambiente

Post-Doc FAPESP grant / Embrapa Meio Ambiente, isis@cnpma.embrapa.br

3 CNPq grant/ Embrapa Meio Ambiente, camila@cnpma.embrapa.br

A collaborative research initiative for the environmental management of ostrich production

\section{Mail Address}

\section{Rodrigues GS}

Pesquisador Embrapa Meio Ambiente

Caixa Postal 069

13820-000. Jaguariúna, SP, Brasil

E-mail: stacheti@cnpma.embrapa.br

\section{Keywords}

APOIA-NovoRural, Eco-cert.Rural, environmental impact assessment, ostrich, scientific cooperation, sustainability indicators.

\section{Acknowledgments}

The sponsorship and institutional support offered by Embrapa Environment, FECOAVESTRUZ-Sudeste and the "Associação de Criadores de Avestruzes do Brasil" (ACAB) were instrumental for this study. We are thankful to Mr. Luiz Robson Muniz, president of FECOAVESTRUZ-Sudeste, for the opportunity of carrying out this research. We are especially grateful to the farmers and administrators Mr. Adair Ribeiro Jr. (Vereda dos Avestruzes, Corumbataí), Mr. Célio Santos (Cooperavestruz, Mogi das Cruzes), Mr. Flávio Henrique de Jesus (GFStruthio, Atibaia), Mr. Marco Antônio Ortega (Sítio Casa Nova, Mairinque), Mr. Marcos Neves (Criavestruz, Pereiras), Mr. Nelson Yutaka Ito (Fazenda Bagres, Mairinque), Mr. Rafael Lucien Tadeu Pereira (Retiro do Avestruz, Itatiba), Mr. Rogério Pascoal Filho e Mrs. Ananda Pascarelli (Terra Brasil Avestruz, Araçatuba), who offered their experience and time during the assessments. The grants offered by FAPESP to Dra. Izilda Rodrigues and by CNPq to Ms. Camila B. Medeiros are gratefully acknowledged.

\section{ABSTRACT}

A collaborative research initiative was proposed by the Federation of Cooperatives of Ostrich Producers of Southeastern Brazil (FECOAVESTRUZ-Sudeste) and Embrapa Environment to training technicians and to develop environmental management procedures in order to establish criteria for the definition of 'Terms of Reference' for sustainable ostrich production for FECOAVESTRUZ associates. Eight farms with different scales of operation were selected by FECOAVESTRUZ-Sudeste for the application of 'integrated environmental indicator systems', designed to develop Environmental Management Reports and to propose best management practices in the farms. The results showed that, in general, indicators relative to Use of inputs and resources, Use of veterinary inputs and raw-materials, and especially Use of energy tended to generate negative impact, because ostrich production was intensive in these farms. On the other hand, this intensive production was also associated with improvements in Income generation and Management and administration, with positive reflexes on Employment quality and Customer respect. The utilization of the 'integrated environmental indicator systems' provide fast and inexpensive procedures designed to prepare producers for the ecocertification and ensuing sustainable origin denomination for ostrich production.

\section{INTRODUCTION}

A collaborative research initiative was proposed by the Federation of Cooperatives of Ostrich Producers of Southeastern Brazil (FECOAVESTRUZ-Sudeste), and was carried out by Embrapa Meio Ambiente (Brazilian Agricultural Research Company - Environmental Unit). This initiative aimed at training technicians to apply 'integrated environmental indicator systems', with the purpose of establishing criteria to define 'Terms of Reference' of sustainable ostrich production to FECOAVESTRUZ associates. This initiative is justified by the special requisites imposed onto the activity, from infrastructure and licensing requirements to health and biosafety precautions (Anuário, 2005/06).

Pursuing this objective, eight selected farms dedicated to ostrich production and with contrasting scales of operation were selected by FECOAVESTRUZ-Sudeste in São Paulo State (Brazil), for conducting case studies aiming at (i) providing an overview of ostrich production contribution for the sustainability of the studied farms, (ii) checking the applicability of sustainability indicator sets in ostrich production, and (iii) assessing the appropriateness of the proposed 'integrated environmental

1 Study presented at the I Latin American Ratite Scientific Workshop, during the XIII World Ostrich Congress, held at the World Trade Center Hotel, São Paulo, Brazil, from 26 to 29 of October of 2006. 
Rodrigues GS, Buschinelli CC de A, Rodrigues IA, Medeiros CB
A Collaborative Research Initiative for the Environmental Management of Ostrich Production indicator systems' for sustainable environmental management (Barnthouse et al.,1998) and ensuing ecocertification for ostrich production in Brazil.

\section{MATERIALS AND METHODS}

\section{Integrated environmental indicator systems ${ }^{2}$}

From the beginning of this collaborative research study, technicians associated with and appointed by FECOAVESTRUZ-Sudeste were trained and involved in the environmental assessments.

Two methodological approaches were used for the environmental assessment of ostrich production. The first was a simplified, low-cost "Basic system for ecocertification of rural activities" (Eco-cert.Rural - Rodrigues et al., 2006). This Eco-cert.Rural system offered a conceptual framework for the definition of the 'Terms of Reference' and the methodological basis for assessing the sustainability of the activity under these 'Terms'. The other applied method was the "Weighed Environmental Impact Assessment System for New Rural Activities" (APOIA-NovoRural, Rodrigues \& Campanhola, 2003). This 'integrated environmental indicator system' focuses on the environmental management of farms on quantitative, analytical basis. This method, as compared to the first, is more detailed and methodologically complex, therefore involving higher costs and taking longer to be completed.

Assessment results of both methods and for all studied farms were consolidated into individualized
'Environmental Management Reports', which were presented to the farmers, and included the conceptual foundation of the studies, as well recommendations for the improvement of practices and technologies aimed at enhancing the sustainability of ostrich production at the involved farms.

\section{Basic system for eco-certification of rural activities (Eco-cert.Rural)}

The Eco-cert.Rural System consists of a set of 24 social-environmental performance criteria for the assessment of an agricultural activity in a farm. It includes 125 indicators, grouped under seven principles and two sustainability dimensions, namely Ecological Performance and Social-environmental Performance. The seven principles concerned with the sustainability of ostrich production in the Eco-cert.Rural System, and the associated criteria are shown in Figure 1. For a complete listing of all indicators and comments on their applicability, see Monteiro \& Rodrigues (2006).

Each criterion consists of a series of socialenvironmental performance indicators agricultural activity calculated in automatic weighing matrices. Each matrix has a number of open cells, where 'change coefficients' obtained for each indicator are introduced. Standardized indicator 'change coefficients' (Table 1) are obtained from field surveys, or interviews with the farmer or farm's manager as to his/her knowledge on the social-environmental performance of ostrich.

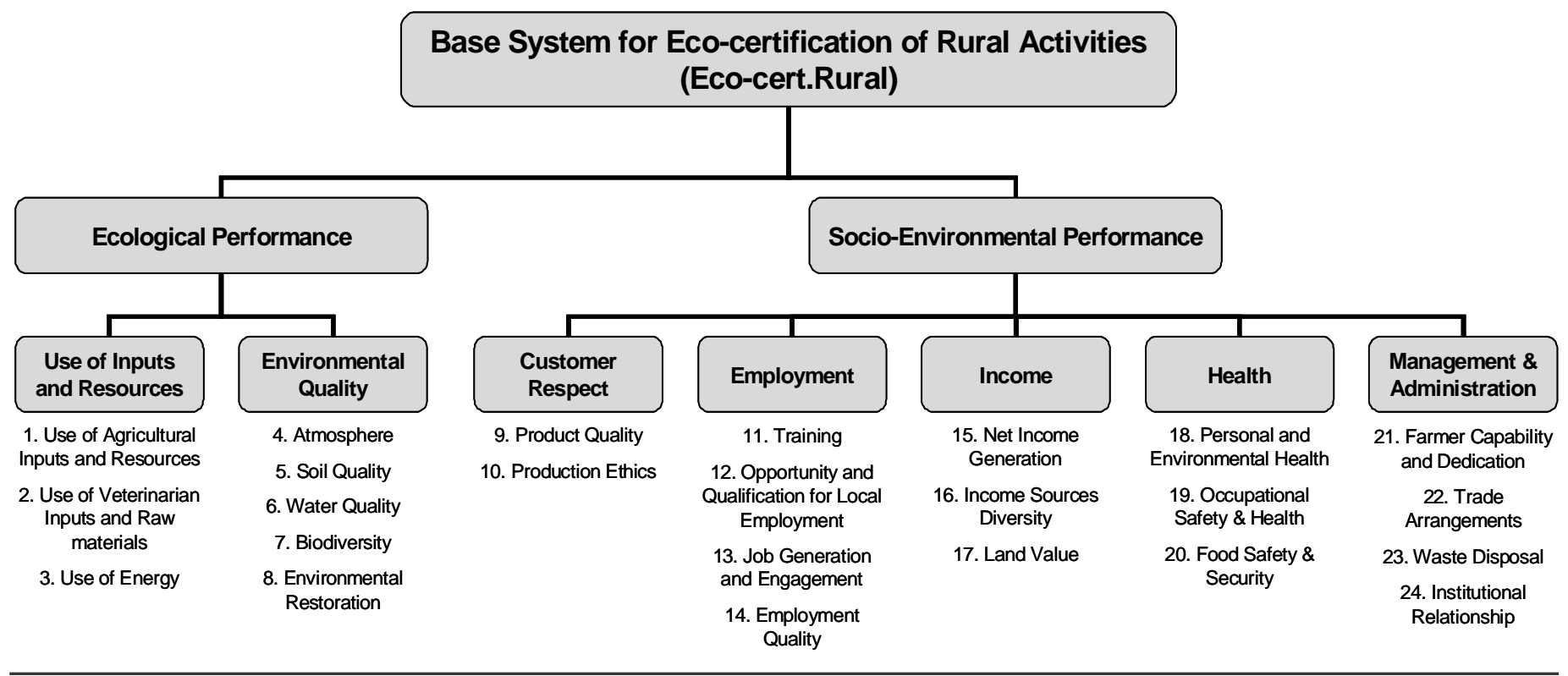

Figure 1 - Diagram of the set of Principles and Criteria applied for socio-environmental performance assessment of ostrich production. Base System for Eco-certification of Rural Activities (Eco-cert.Rural).

\footnotetext{
2 To access to the operational "Integrated Environmental Indicators Systems", please contact the authors.
} 
Rodrigues GS, Buschinelli CC de A, Rodrigues IA, Medeiros CB
Table 1 - Effects caused by the agricultural activity in the studied situation and indicator change coefficients to be inserted into the cells of the weighing Environmental Impact Assessment matrices.

Effect of the agricultural activity

under the management conditions

studied

Major increase in the indicator

Moderate increase in the indicator

Indicator unaffected

Moderate decrease in the indicator

Major decrease in the indicator

production as practiced under the specific management conditions of the farm.

In addition, each matrix includes weighing factors related to the scale in which the indicator change coefficient occurred under the studied situation. The occurrence scale of a component expresses the local spatial magnitude of the effects, as follows:

i. Near environment when the change coefficient effects are restricted to the productive unit where the agricultural activity is being conducted;

ii. Proximate environment when the change coefficient effects extend beyond the productive unit, but within the boundaries of the farm;

iii. Surrounding environment when the change coefficient effects reach an area or environment beyond the boundaries of the farms.

The weighing factors for occurrence scale of the indicators are fixed, as shown in Table 2. These values are assigned to imply a proportionally larger impact
A Collaborative Research Initiative for the Environmental Management of Ostrich Production index when the agricultural activity affects areas or environments beyond the boundaries of the farm. A typical example of indicator weighing matrix for Environmental Restoration criteria, is shown in Figure 2.

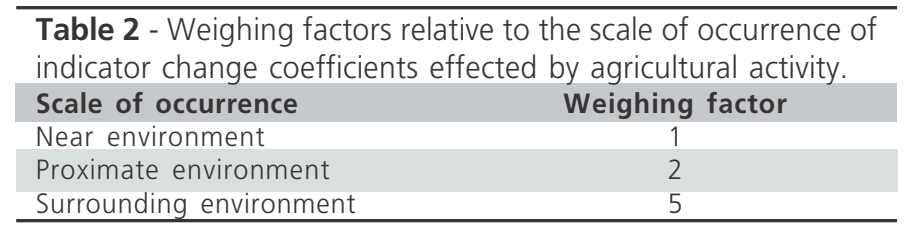

Once all indicator change coefficients are inserted into the weighing matrices, sequentially for Ecological Performance and Social-environmental Performance, the environmental impact coefficient of each criterion is expressed in the Activity Performance spreadsheet. Finally, an Agricultural activity Performance Index is calculated for the activity under the conditions of the establishment.

The Eco-cert.Rural System aims at providing farmers with an swift and inexpensive procedure that allows the assessment, the recommendation, and the documentation of sustainable management practices, contributing for insertion in the marketplace of special products (Viglizzo, 2005). These assessment results may help ostrich production managers to select management practices and technologies for the improvement of the farm's social-environmental performance. To decision-makers and organizations, Eco-Cert.Rural System assessments may foster the

\begin{tabular}{|c|c|c|c|c|c|c|c|}
\hline \multicolumn{8}{|c|}{\begin{tabular}{l|l} 
Table of change coefficients for variable \\
\end{tabular}} \\
\hline \multirow{2}{*}{\multicolumn{3}{|c|}{$\begin{array}{c}\text { Environmental } \\
\text { Restoration }\end{array}$}} & \multicolumn{4}{|c|}{\begin{tabular}{|c|} 
Environmental restorarion varables \\
\end{tabular}} & \multirow[b]{2}{*}{$\begin{array}{l}\text { weighing } \\
\text { factor } \\
\text { check }\end{array}$} \\
\hline & & & Degraded soils & $\begin{array}{c}\text { Degraded } \\
\text { ecosystems }\end{array}$ & $\begin{array}{l}\text { Legally-defined } \\
\text { Preservation } \\
\text { Areas }\end{array}$ & $\begin{array}{c}\text { Mandatory } \\
\text { Protection Areas }\end{array}$ & \\
\hline \multirow{5}{*}{ 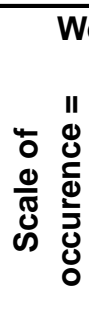 } & ighing factor & & 0,2 & 0,2 & 0,2 & 0,4 & \multirow[t]{5}{*}{1} \\
\hline & No-effect & $\begin{array}{c}\text { Mark } \\
\text { with } \mathrm{X}\end{array}$ & & & & & \\
\hline & Near & 1 & 3 & & & 1 & \\
\hline & Proximate & 2 & & & 3 & & \\
\hline & Surrounding & 5 & & 3 & & & \\
\hline \multicolumn{3}{|c|}{$\begin{array}{l}\text { Impact Coefficient }= \\
\text { (change coefficients * } \\
\text { weighing factors) }\end{array}$} & 0,6 & 3 & 1,2 & 0,4 & 5,2 \\
\hline
\end{tabular}

Figure 2 - Typical Environmental Indicators Weighing Matrix, for the Environmental Restoration Criterion of the Base System for Ecocertification of Rural Activities (Eco-cert.Rural). 
Rodrigues GS, Buschinelli CC de A, Rodrigues IA, Medeiros CB
A Collaborative Research Initiative for the Environmental Management of Ostrich Production definition of control measures and policies to improvethe environmental performance of agricultural activities. Overall, this system favors a benchmarking process for the identification and implementation of Best Management Practices, aligned with locally sustainable development plans, and eco-certification interests.

\section{Weighed Environmental Impact Assessment System for Agricultural Activities (APOIA-NovoRural)}

The APOIA-NovoRural System consists of a set of environmental indicator weighing matrices (Rodrigues, 1998), formulated for the systemic assessment of an agricultural activity, according to five sustainability dimensions: i) Landscape Ecology, ii) Environmental Quality (Atmosphere, Water, and Soil), iii) Socialcultural Values, iv) Economic Values, and $v$ ) Management and Administration. These dimensions are integrated to encompass the productive farm system within the local environment and market setting. The farm represents the spatial scale of the analysis, which quantitatively and analytically assesses the effects of the agricultural activity on each and every indicator constructed for the aforementioned five dimensions, and automatically calculates the impact indexes, according to appropriate weighing factors.

The System integrates sixty-two indicators, derived from a literature review on Environmental Impact Assessment methodologies (Dee et al., 1973; Canter, 1979; Neher, 1992; Bockstaller et al., 1997; McDonald \& Smith, 1998; Rodrigues, 1998; Girardin et al.; 1999;
Bosshard, 2000; Rodrigues et al., 2000; Rossi \& Nota, 2000), group discussions, and workshops. The indicators were selected, designed, and organized to encompass the range of possible environmental effects directly defined as impacts, and to be applicable to any agricultural activity. The complete set of indicators of the APOIANovoRural System, and their respective measurement units used in the field and laboratory analyses, can be found in Rodrigues \& Moreira-Viñas (2007).

The data required for filling many of the indicator weighing matrices are administrative and historical knowledge of the farm manager, which are obtained by interview supported by a structured questionnaire. Other indicators, related to soil and water quality, are obtained by instrumental field survey and laboratory analyses. All indicator weighing matrices are designed to translate indicator variables and attributes into environmental impact indices, graphically expressed relative to an utility function (0 to 1 normalized scale, with benchmark compliance value set at 0.7; Bisset, 1987) for the indicator (Figure 3). These utility functions express environmental performance benchmarks for each particular indicator, and were derived from individual sensitivity and probability tests of each indicator (Girardin et al., 1999).

The results of the assessments are graphically presented in printable form, expressing the performance of the evaluated activity for each one of the indicators comparatively to the defined benchmark. The results of all indicators are then combined by a mean utility value for each dimension considered, and a graph presenting a synthesis of the impact of the

\begin{tabular}{|c|c|c|c|c|c|c|c|c|c|c|}
\hline \multirow[b]{2}{*}{$\begin{array}{c}\text { Occupational } \\
\text { safety and health }\end{array}$} & \multicolumn{4}{|c|}{$\begin{array}{c}\text { Table of numer of people exposed } \\
\text { Peril factors }\end{array}$} & \multicolumn{6}{|c|}{ Harm factors } \\
\hline & 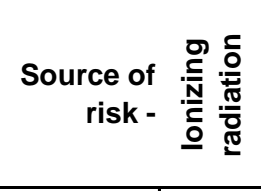 & $\begin{array}{l}\frac{y}{\infty} \\
\frac{2}{0} \\
\frac{0}{x} \\
\text { w }\end{array}$ & 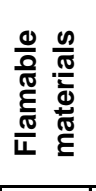 & 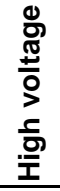 & $\frac{\Phi}{\mathscr{0}}$ & 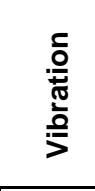 & $\begin{array}{l}\frac{0}{0} \\
\frac{0}{2} \\
\frac{\mathbb{d}}{1}\end{array}$ & 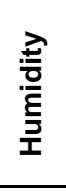 & 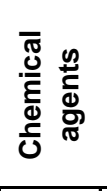 & 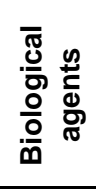 \\
\hline $\begin{array}{r}\begin{array}{r}\text { Total number of } \\
\text { workers - }\end{array} \\
\end{array}$ & 15 & & & & 1 & & 9 & & & \\
\hline \multicolumn{11}{|c|}{ Occupational safety index = } \\
\hline \begin{tabular}{rr|} 
IOccupS & \multicolumn{2}{c|}{ Utility } \\
10 & 0 \\
8 & 0.1 \\
6 & 0.2 \\
4 & 0.4 \\
2 & 0.6 \\
1 & 0.8 \\
0 & 1
\end{tabular} & $\begin{array}{c}2 \\
\text { Occupational }\end{array}$ & fety a & 6 & & $\overrightarrow{10}$ & $\begin{array}{l}\text { Ratio } \\
\text { Coeffici } \\
a= \\
b= \\
c= \\
d= \\
\text { U-IOc }\end{array}$ & $\begin{array}{l}\text { st fit e } \\
\text { functio } \\
\text { s: } \\
1.00 \\
-0.10 \\
0.15 \\
0.00 \\
\text { upS }=\end{array}$ & $\begin{array}{l}\text { uatio } \\
\text { n: } y=(\end{array}$ & $\frac{n \text { for Ut }}{a+b x) /(1+}$ & $\frac{i t y}{\left.x+d x^{\wedge} 2\right)}$ \\
\hline
\end{tabular}

Figure 3 - Typical weighing matrix of the APOIA-NovoRural environmental impact assessment system, showing the Occupational safety and health indicator. 
Rodrigues GS, Buschinelli CC de A, Rodrigues IA, Medeiros CB
A Collaborative Research Initiative for the Environmental Management of Ostrich Production five assessment dimensions of the activity as a whole is designed.

Field surveys were carried out in eight farms selected by FECOAVESTRUZ-Sudeste during 2006. Proportions of areas occupied by agricultural activities, natural habitats, permanent protection areas, and legal reservation were estimated by GPS reference points taken in the field, and plotted onto satellite images and farm maps. Some water quality indicators $\left(\mathrm{O}_{2}, \mathrm{pH}\right.$, Conductivity, Turbidity) were measured in the field using a Horiba (U-10) Multi-parameter Probe. Nitrate was measured with a Merck RQ-Flex field colorimeter. Coliform levels were estimated using Technobac (AlphaTecnoquímica) culture media strips. Water samples were submitted to the laboratory for Phosphate and Chlorophyll content analyses using a HACH spectrophotometer. Soil samples were analyzed for all routine chemical parameters. Other indicators were assessed according to documents and personal knowledge of the farmers.

Environmental performances of the different farms were compared as to the congruence of impact indices obtained in the weighing matrices with descriptive statistics. Recommendations of alternative management practices and technologies drawn from the results were consolidated in individual Environmental Management Reports issued to the farmers.

\section{RESULTS AND DISCUSSION}

\section{Eco-cert.Rural}

The six farms assessed using Eco-cert.Rural included small farms dedicated to ostrich breeding up to large farms, which had breeding-to-finishing activities, including third-party customers. There was also one farm dedicated only to incubation for third-party associates. Despite the wide variation in scale and production systems in this sample, mean environmental performance result, normalized for the method scale (from +15 to -15 [Figure 4]), shows that indicators relative to Use of inputs and resources (criterion 1, see Figure 1), Use of veterinary inputs and raw-materials (criterion 2), and particularly Use of energy (criterion $3)$, tended to generate negative performance indices. Ostrich production developed in these farms is considered as intensive. This result implies that actions to improve the efficiency of the use of inputs and resources are recommended, such as saving energy, local production of feed, and special care in the use of water.

On the other hand, this intensification of production was associated with improvement in Income generation (criteria 15-17) and Management and administration (criteria 21-24) indicators in these farms, with positive impact on Employment quality (criteria 11-14) and Customer respect (criteria 9 and 10, see Figure 1), which were favorable records observed for ostrich production. In average, according to the assessments carried out, ostrich production positively contributed for the sustainability of the studied farm, favoring overall social-environmental performance and improving the quality of life of the involved personnel.

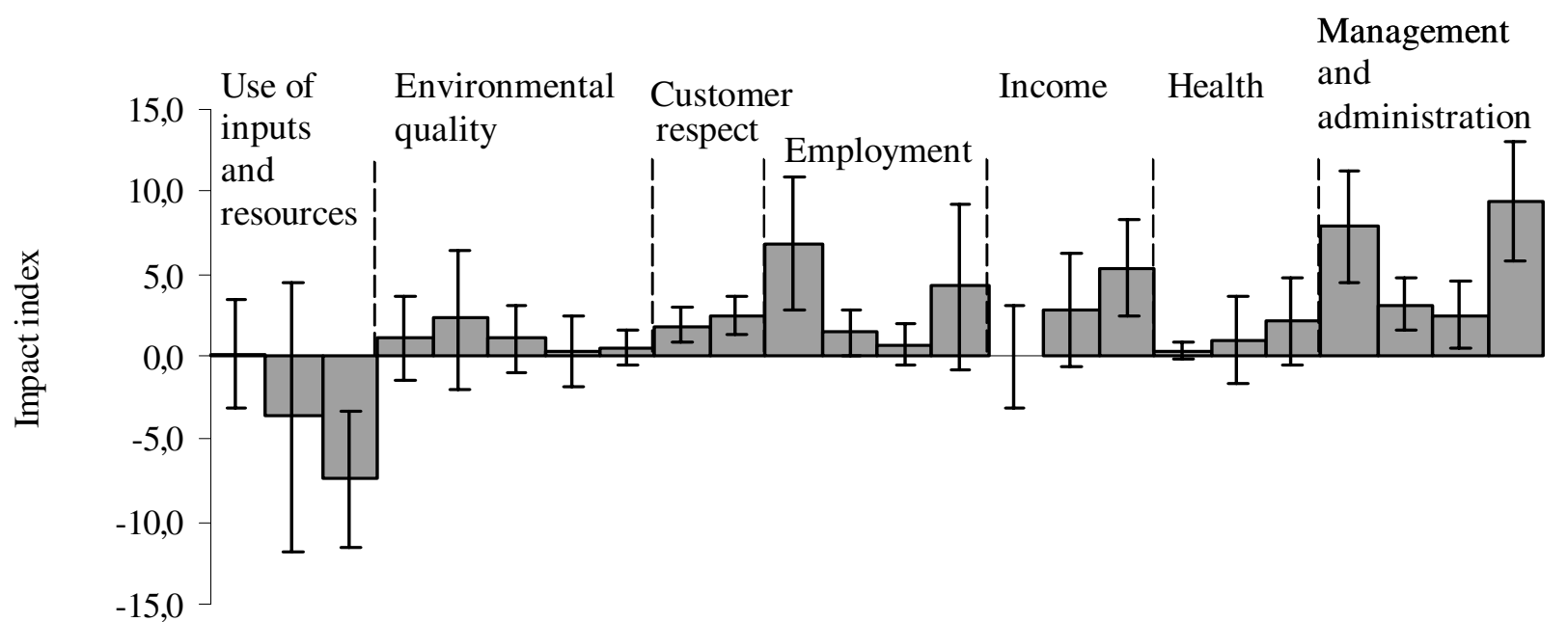

$\begin{array}{llllllllllllllllllllllll}\text { Criteria: } 1 & 2 & 3 & 4 & 5 & 6 & 7 & 8 & 9 & 10 & 11 & 12 & 13 & 14 & 15 & 16 & 17 & 18 & 19 & 20 & 21 & 22 & 23 & 24\end{array}$ See Figure 1

Figure 4 - Social-environmental evaluation results (mean impact index \pm sd) for the 24 performance criteria of the Eco-cert.Rural System, in six ostrich production farms in São Paulo State (Brazil). For Criteria specification, see Figure 1. 
Rodrigues GS, Buschinelli CC de A, Rodrigues IA, Medeiros CB Management of Ostrich Production

\section{APOIA-NovoRural}

The results of the environmental impact assessment case studies carried out with the APOIA-NovoRural System in two farms dedicated to ostrich production are presented in Figure 5. Both establishments reached Impact Indices above the benchmark compliance value defined by the method (0.70), indicating that ostrich production favorably contributed for sustainability in the studied situations. Contrasting results between the farms were observed for Landscape Ecology, Water Quality, and Economic Values. The set of indicators relative to Soil Quality was below the benchmark compliance value established by the assessment system, indicating low soil fertility in both farms. In general, soils were deficient in phosphate and potassium . In Farm B, in organic matter content losses in the paddocks where ostriches were kept contributed for a lower soil quality index (0.60), as compared to Farm A (0.64).

Landscape Ecology indicators in Farm A (0.69) show compliance with habitat conservation requisites (Permanent Preservation Areas, Legal Reservation, Fauna Corridors), as defined by the Brazilian legislation. In Farm B, a large dam for hydroelectric power production was built by a Government Concessionary Company, with no recovery of forests on the dam shores (which are legally defined as Permanent Preservation Areas), and consequent incompliance with the legal requisites of Permanent Preservation Areas, and lower index for this dimension (0.62). Despite its negative impact on environmental status and on Landscape Ecology in Farm B, this situation was not caused by ostrich production. Moreover, the indicator relative to Productive diversity was very low in both farms, indicating sustainability is at risk, as ostrich production was the only predominant productive activity.

Water Quality indicators were very different between the studied farms, mostly due to high Nitrate levels and Coliform bacteria both in surface and groundwater of Farm A. Groundwater nitrate levels in Farm B were also high, but below toxic levels for ostriches (Holle, 2002). Despite these low indices for the mentioned indicators, the general Water Quality indices were above the benchmark compliance value (0.7) in both farms (Table 3).

Very good results were obtained for all indicators of the Economic Values dimension in Farm A (0.83), primarily reflecting the long period of ostrich production in this farm (1996), its large-scale operations (around 2,500 birds), and current favorable insertion in the market. On the other hand, as Farm B is starting to produce ostriches (operations begun in 2004), Income generation and Current indebtedness levels showed low performance values, resulting in a 0.67 index for the Economic Values dimension.
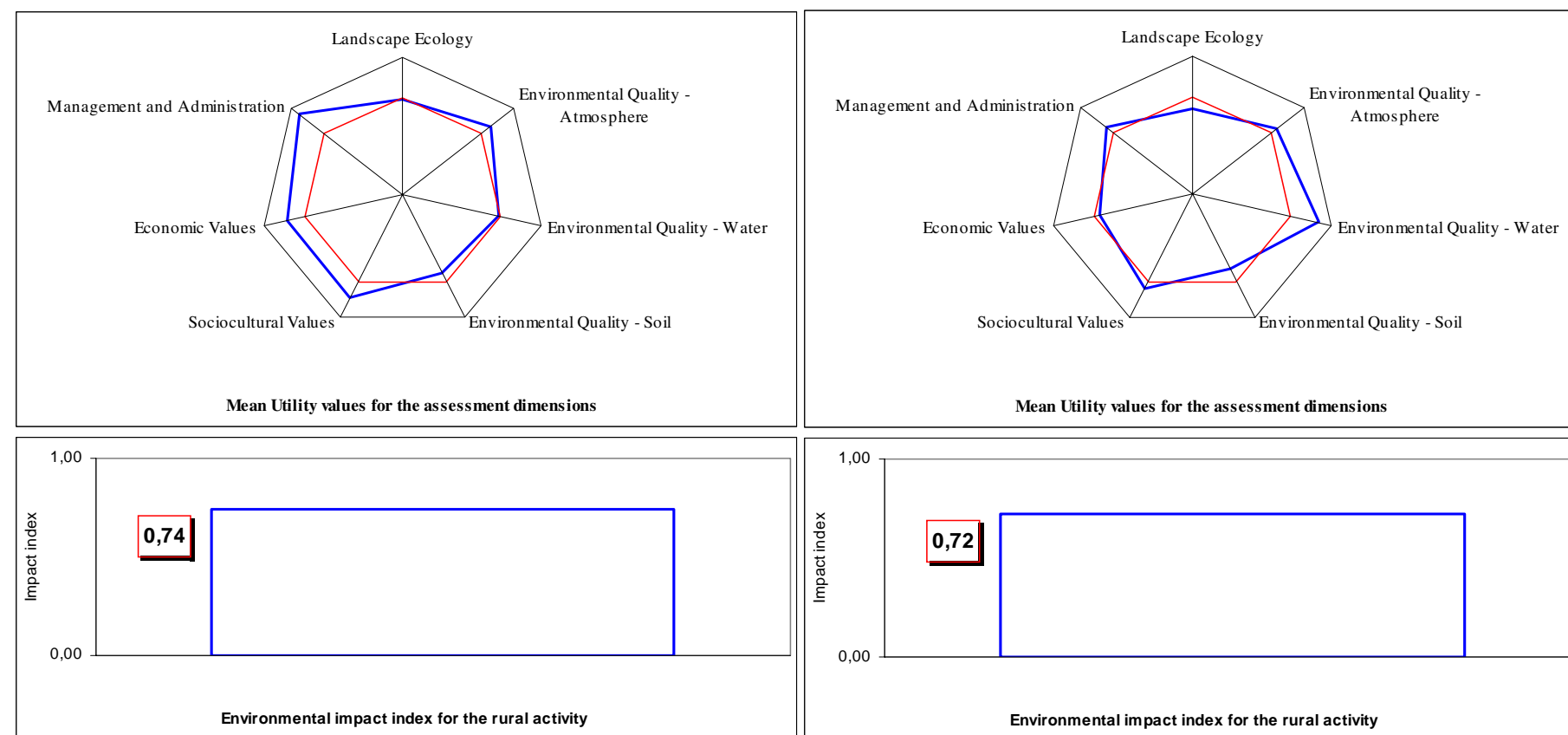

Establishment A

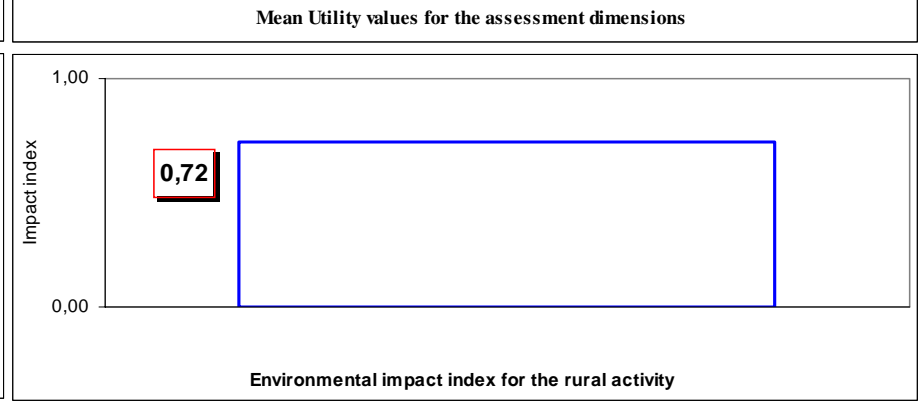

Establishment B

Figure 5 - Environmental Impact Assessment results obtained with the APOIA-NovoRural System, for two ostrich production farms in São Paulo State (Brazil). 


\begin{tabular}{|c|c|c|c|c|c|c|}
\hline \multirow{2}{*}{$\begin{array}{l}\text { Indicators and measurement } \\
\text { units }\end{array}$} & \multicolumn{3}{|c|}{ Farm A } & \multicolumn{3}{|c|}{ Farm B } \\
\hline & $\begin{array}{l}\text { Parameter value } \\
\text { before }\end{array}$ & $\begin{array}{l}\text { Parameter } \\
\text { value after }\end{array}$ & $\begin{array}{l}\text { Utility } \\
\text { value }\end{array}$ & $\begin{array}{l}\text { Parameter } \\
\text { value before }\end{array}$ & $\begin{array}{l}\text { Parameter } \\
\text { value after }\end{array}$ & $\begin{array}{l}\text { Utility } \\
\text { value }\end{array}$ \\
\hline Dissolved oxygen (mg / L) & 9.8 & 10.2 & 1.0 & 13.8 & 13.3 & 1.0 \\
\hline Coliforms (number / 100 ml) & 420 & 780 & 0.23 & 0.0 & 0.0 & 1.0 \\
\hline $\mathrm{pH}$ & 4.9 & 6.3 & 0.99 & 8.9 & 8.8 & 0.92 \\
\hline Nitrate (mg / L) & 6.2 & 3.5 & 0.61 & 0.9 & 0.9 & 0.94 \\
\hline Phosphate (mg / L) & 0.11 & 0.20 & 0.91 & 0.02 & 0.02 & 1.0 \\
\hline Turbidity (Nephelometric units) & 0.0 & 4.0 & 1.0 & 12.0 & 11.0 & 1.0 \\
\hline Conductivity $(\mu \mathrm{S} / \mathrm{cm})$ & 0.030 & 0.034 & 0.95 & 0.206 & 0.202 & 0.95 \\
\hline Visual pollution (percent of time present) & nt) $100 \%$ wo & $100 \%$ wo & 1.0 & $100 \%$ wo & $100 \%$ wo & 1.0 \\
\hline Pesticides (percent of area sprayed) & $100 \%$ wo & $100 \%$ wo & 1.0 & $99 \%$ wo & $99 \%$ wo & 1.0 \\
\hline Coliforms groundwater (number / $100 \mathrm{ml}$ & ml) $\quad 240$ & 240 & 0.33 & 0.0 & 0.0 & 1.0 \\
\hline Nitrate groundwater (mg / L) & 14.1 & 14.1 & 0.0 & 11.6 & 11.6 & 0.04 \\
\hline Conductivity groundwater $(\mu \mathrm{S} / \mathrm{cm})$ & 0.047 & 0.047 & 0.95 & 0.158 & 0.158 & 0.95 \\
\hline Water Quality Index & 0.75 & 0.90 & & & & \\
\hline
\end{tabular}

Social-cultural Values and Management and Administration dimensions were enhanced by ostrich production in the studied farms $(0.84$ and $0.94 ; 0.76$ and 0.78 , for Farms $A$ and $B$, respectively). Special reference must be made to the indicators Manager profile and dedication and Institutional relationship, which demonstrate the importance of managerial initiatives for the improvement of the performance of productive activities.

The obtained Environmental Impact indices (0.74 and 0.72 , for Farms $A$ and $B$, respectively) show that ostrich production generally made positive contributions for the sustainability of the farms. The APOIANovoRural System proved to be a comprehensive method, and adequate for sustainability assessment and environmental management of ostrich production. Ostrich production performance results as to certain environmental indicators offer a diagnostic tool to farmers, indicating when the activity complies with defined legal standards and benchmarks. Additionally, the indicators express the relative variation and temporal trend of the impacts imposed by the activity, indicating courses of action towards local sustainable management. The APOIA-NovoRural environmental impact index is proposed as a parameter for quality certification of ostrich production, aiming at achieving ecological soundness, economic vitality, and socialcultural equity for local sustainable development.

\section{CONCLUSIONS}

Three main conclusions can be drawn from the collaborative research initiative presented in this study:

1. Important contributions of ostrich production for the sustainability of the studied farms were observed in the present study, particularly as to indicators relative to the Management and Administration dimension;

2. The organization of producers in Cooperatives, aiming at defining a 'Term of Reference for Environmental Management', upon the basis offered by the 'integrated environmental indicators systems' included in the present study, is an important step toward the improvement of Brazilian ostrich production, in the present moment of consolidation of the national market;

3. The initiative of developing a sustainable environmental management program for ostrich production, as organized by FECOAVESTRUZSudeste in response to the demands of the associated Cooperatives, may make this activity more visible, contributing for better market insertion and for strengthening ostrich production in Brazil.

\section{REFERENCES}

Anuário da Estrutiocultura Brasileira. Associação dos Criadores de Avestruzes do Brasil (ACAB). São Paulo: Terra Comunicação Editorial; 2005/2006.

Barnthouse L, Biddinger G, Cooper W, Fava J, Gillett J, Holland M, Yosie T editors. Sustainable environmental management [Pellston Series Workshops]. Pellston: Society of Environmental Toxicology and Chemistry. 1998. p.102.

Bisset R. Methods for environmental impact assessment: a selective survey with case studies. In: Biswas AK, Geping Q, editors. Environmental impact assessment for developing countries. London: Tycooly International; 1987. p. 3-64.

Bockstaller C, Girardin P, Van der Werf HMG. Use of agro-ecological indicators for the evaluation of farming systems. European Journal of Agronomy 1997; 7:261-270. 
Rodrigues GS, Buschinelli CC de A, Rodrigues IA, Medeiros CB
A Collaborative Research Initiative for the Environmental Management of Ostrich Production
Bosshard A. A methodology and terminology of sustainability assessment and its perspectives for rural planing. Agriculture, Ecosystems and Environment 2000; 77: 29-41.

Canter LW, Hill GL. Handbook of variables for environmental impact assessment. Ann Arbor (MI): Ann Arbor Science Publishers; 1979. p. 203.

Dee N, Baker J, Drobny N, Duke K, Whitman I, Fahringer D. An environmental evaluation system for water resource planning. Water Resources Research 1973; 9(3):523-535.

Girardin P, Bockstaller C, Van der Werf H. Indicators: tools to evaluate the environmental impacts of farming systems. Journal of Sustainable Agriculture 1999; 13(4):5-21.

Holle D. Water Quality for Ostriches. Blue Mountain Ostrich Nutrition. Bulletin 78; 2002 [Cited 2006 out 20]. Available from: http//www. Ostrich\%20\&\%20Nitrates.htm.

Mcdonald GT, Smith CS. Assessing the sustainability of agriculture at the planning stage. Journal of Environmental Management 1998; 52:15-37.

Monteiro RC, Rodrigues GS. A system of integrated indicators for socio-environmental assessment and eco-certification in agriculture - Ambitec-Agro. Journal of Technology Management and Innovation 2006; 1(3): 47-59.

Neher D. Ecological sustainability in agricultural systems: definition and measurement. Journal of Sustainable Agriculture 1992; 2(3): $51-61$.

Rodrigues GS. Avaliação de impactos ambientais em projetos de pesquisas: fundamentos, princípios e introdução à metodologia. [Documentos 14]. Jaguariúna (SP): Embrapa Meio Ambiente; 1998.

Rodrigues GS, Buschinelli CCA, Irias LJM, Ligo MAV. Avaliação de impactos ambientais em projetos de pesquisa II: avaliação da formulação de projetos - versão I [Boletim de Pesquisa 10]. Jaguariúna (SP): Embrapa Meio Ambiente; 2000.

Rodrigues GS, Campanhola C. Sistema integrado de avaliação de impacto ambiental aplicado a atividades do Novo Rural. Pesquisa Agropecuária Brasileira 2003; 38(4): 445-451.

Rodrigues GS, Buschinelli CCA, Rodrigues IA, Monteiro RC, Viglizzo E. Sistema base para eco-certificação de atividades rurais [Boletim de Pesquisa e Desenvolvimento 37]. Jaguariúna: Embrapa Meio Ambiente; 2006.

Rodrigues GS, Moreira-Viñas A. An environmental impact assessment system for responsible rural production in Uruguay. Journal of Technology Management and Innovation 2007; 2(1): 42-54.

Rossi R, Nota D. Nature and landscape production potentials of organic types of agriculture: a check of evaluation criteria and parameters in two Tuscan farm-landscapes. Agriculture, Ecosystems and Environment 2000; 77:53-64.

Viglizzo E. Tendencias y demandas de tecnología ambiental en eco-regiones predominantes del Cono Sur. [Serie Resúmenes Ejecutivos, 10]. Montevideo: PROCISUR/BID; 1999. [cited 2005 ago. 1]. Available from: http://www.procisur.org.uy/10vig.pdf.(Footnotes) 